\title{
PHYSIOLOGICAL RESPONSES OF TWO TROPICAL WEEDS TO SHADE. I. GROWTH AND BIOMASS ALLOCATION ${ }^{1}$
}

\author{
MOACYR BERNARDINO DIAS-FILHO²
}

\begin{abstract}
Ipomoea asarifolia (Desr.) Roem. \& Schultz (Convolvulaceae) and Stachytarpheta cayennensis (Rich) Vahl. (Verbenaceae), two weeds found in pastures and crop areas in Brazilian Amazonia, were grown in controlled environment cabinets under high $\left(800-1000 \mu \mathrm{mol} \mathrm{m}^{-2} \mathrm{~s}^{-1}\right)$ and low (200-350 $\left.\mu \mathrm{mol} \mathrm{m}^{-2} \mathrm{~s}^{-1}\right)$ light regimes during a 40-day period. For both species leaf dry mass and leaf area per total plant dry mass, and leaf area per leaf dry mass were higher for low-light plants, whereas root mass per total plant dry mass was higher for high-light plants. High-light $S$. cayennensis allocated significantly more biomass to reproductive tissue than low-light plants, suggesting a probably lower ability of this species to maintain itself under shaded conditions. Relative growth rate (RGR) in I. asarifolia was initially higher for high-light grown plants and after 20 days started decreasing, becoming similar to low-light plants at the last two harvests (at 30 and 40 days). In S. cayennensis, RGR was also higher for high-light plants; however, this trend was not significant at the first and last harvest dates (10 and 40 days). These results are discussed in relation to their ecological and weed management implications.
\end{abstract}

Index terms: allocation patterns, growth analysis, Amazonia, Ipomoea asarifolia, Stachytarpheta cayennensis.

\section{RESPOSTAS FISIOLÓGICAS DE DUAS PLANTAS INVASORAS TROPICAIS AO SOMBREAMENTO. I. CRESCIMENTO E ALOCAÇÃO DE BIOMASSA}

\begin{abstract}
RESUMO - Ipomoea asarifolia (Desr.) Roem. \& Schultz (Convolvulaceae) e Stachytarpheta cayennensis (Rich) Vahl. (Verbenaceae), duas plantas invasoras encontradas em pastagens e áreas agrícolas da Amazônia brasileira, foram cultivadas durante 40 dias, em câmaras de crescimento sob alto (800-1000 $\mu \mathrm{mol} \mathrm{m} \mathrm{m}^{-2} \mathrm{~s}^{-1}$, "sol") e baixo (200-350 $\mu \mathrm{mol} \mathrm{m}^{-2} \mathrm{~s}^{-1}$, "sombra") regime de luz. Em ambas as espécies a razão de massa e de área foliar por unidade de massa total da planta, e a área foliar por unidade de massa foliar foram maiores na sombra, enquanto a proporção de biomassa alocada para as raízes foi maior nas plantas ao sol. Em S. cayennensis a alocação de biomassa para tecido reprodutivo foi maior nas plantas ao sol, sugerindo uma provável menor habilidade dessa espécie de se manter sob condições de sombreamento. A taxa de crescimento relativo (TCR) em I. asarifolia foi, inicialmente, maior nas plantas ao sol, e após 20 dias passou a decrescer, tornando-se semelhante entre tratamentos nas últimas duas avaliações (aos 30 e 40 dias). Em S cayennensis, a TCR foi também maior em plantas ao sol, porém esta tendência não foi significativa na primeira e última avaliação (10 e 40 dias). Esses resultados são discutidos com relação às suas importâncias ecológica e de manejo.
\end{abstract}

Termos para indexação: alocação de biomassa, análise de crescimento, Amazônia, Ipomoea asarifolia, Stachytarpheta cayennensis.

\section{INTRODUCTION}

All plants have the ability to modify their developmental patterns in response to the light environ-

\footnotetext{
${ }^{1}$ Accepted for publication on August 29, 1998.

2 Agronomist, Ph.D., Embrapa-Centro de Pesquisa Agroflorestal da Amazônia Oriental, Caixa Postal 48, CEP 66017-970 Belém, PA, Brazil. E-mail: moacyr@ufpa.br
}

ment (Holt, 1995). However, the nature of photomorphogenic responses can vary considerably among species according to their acclimation capacity (i.e., morphological plasticity) and depending upon the quantity and quality of light (e.g., Clough et al., 1979, 1980; Walters \& Field, 1987; Givnish, 1988; Seemann, 1989; Groninger et al., 1996). The ability of an individual species to successfully grow in a low or high-light environment (holding quality 
constant) can be assessed by determining how efficiently and how rapidly allocation patterns and physiological behavior are adjusted in response to a particular light environment.

The present research involved work with two species: Ipomoea asarifolia (Desr.) Roem. \& Schultz, a fast-growing Convolvulaceae vine, and Stachytarpheta cayennensis (Rich) Vahl., a relatively slow-growing Verbenaceae shrub. Both are recognized as important perennial $\mathrm{C}_{3}$ weedy species from pastures and crop areas in the Brazilian Amazonia (Dias-Filho, 1990). Although native to tropical America, S. cayennensis also occurs as a weed in Australia (Kleinschmidt \& Johnson, 1987), Hawaii (Haselwood \& Motter, 1983) and India (Nair et al., 1982). Also, many Ipomoea species are considered as important weeds from warm temperate zones (Elmore et al., 1990). In active pasture areas, the occurrence of $S$. cayennensis has been related to overgrazing, being more common in areas with little or no vegetation cover, while I. asarifolia, although capable of starting growth in relatively shaded areas along fences and near fallen tree trunks, usually occupies available sunny areas (Dias-Filho, 1990). In abandoned pasture and crop areas in Amazonia, both species tend to disappear as these areas become increasingly invaded by shrubs and small tree. The above observations may suggest that light, among other resources, might be an important determinant of these species' presence, and may also play an important role in their ability to establish and successfully compete with crop and pasture species.

The objective of the present study was to determine the sun-shade acclimation of I. asarifolia and S. cayennensis by measuring growth rate and biomass allocation patterns of these species developed at high and low photon flux densities. The hypothesis to be tested was that the spatial patterns in the distribution of these species observed in the field may, to some extent, be reflected in their responses to the light environment

\section{MATERIAL AND METHODS}

\section{Plant material and growing conditions}

Ipomoea asarifolia (Convolvulaceae) and Stachytarpheta cayennensis (Verbenaceae) seeds were collected from plants growing in pasture areas in the eastern Brazilian Amazonia ( $\left.2^{\circ} 58^{\prime} \mathrm{S}\right)$. Seeds were germinated on filter paper in petri dishes and then planted individually in $15 \mathrm{~cm}$ plastic pots with a mixture of peat:vermiculite:perlite $(1: 1: 1)$. Plants were initially grown in a greenhouse at temperatures of $24 \pm 2.2^{\circ} \mathrm{C}$ (minimum) to $33 \pm 2.1^{\circ} \mathrm{C}$ (maximum) and a maximum photon flux density (PFD) of approximately $900 \mu \mathrm{mol} \mathrm{m}^{-2} \mathrm{~s}^{-1}$. Following expansion of the first two leaves (about 21 days after germination), plants were transferred from the greenhouse to two Conviron growth chambers (Model PGW36. Controlled Environments, Inc. Pembina, ND) set at $28 / 24^{\circ} \mathrm{C}$ day/night air temperatures, $70 \%$ relative humidity, and 12-h photoperiod. Before transference to the growth chambers, seedlings from each species were divided into five size classes, and each class was randomly assigned to a replication (block).

Within each growth chamber, a high- and a low-light environment were simulated by placing multiple layers of neutral density shade cloth beneath the light source of half of each growth chamber. Light, monitored throughout the experiment with a light meter (Model LI-1905 light meter, Li-Cor, Inc. Lincoln, NE) at canopy height, ranged between 800 and $1000 \mu \mathrm{mol} \mathrm{m}^{-2} \mathrm{~s}^{-1}$ for high-light and between 200 and $350 \mu \mathrm{mol} \mathrm{m}^{-2} \mathrm{~s}^{-1}$ for low-light treatments.

All pots were watered daily to full capacity with deionized water and fertilized every five days with $50 \mathrm{~mL}$ per pot of a water soluble fertilizer solution $(15: 30: 15$. $\left.\mathrm{N}: \mathrm{P}_{2} \mathrm{O}_{5}: \mathrm{K}_{2} \mathrm{O} ; 3.5 \mathrm{~g} \mathrm{~L}^{-1}\right)$.

\section{Growth analysis}

For both species five harvests were made. The first harvest was on the day plants were transferred to the growth chambers (Day 0), and the others 10, 20, 30 and 40 days later $(n=5$ per harvest and light treatment). At each harvest plant material was divided into leaf, support tissue (stem and petiole), reproductive tissue (flower spikes) (for $S$. cayennensis only) and root. Leaves were removed and leaf area measured using a leaf area meter (Model LI-3000. Li-Cor, Inc. Lincoln, NE) and conveyor belt assembly (Model LI-3050. Li-Cor, Inc. Lincoln, NE). Leaf area was measured three times for each individual leaf and the final area was the mean of these three measurements. Plant dry weight was obtained by drying the plant material in an oven at $70^{\circ} \mathrm{C}$ for 48 hours. Attributes measured for each plant at each harvest were used to estimate relative growth rate (change in dry weight per total dry weight of plant per day, RGR) and biomass allocation patterns: leaf area ratio (leaf area per unit dry mass of whole plant, LAR), specific leaf area (leaf area per unit of leaf dry mass, SLA) and leaf, stem and root mass ratios 
(respectively, leaf, stem or root dry mass per unit of dry mass of whole plant, LMR, SMR and RMR). For $S$. cayennensis it was also estimated the amount of biomass allocated to reproductive structures (flower spike dry mass per unit of dry mass of whole plant). All of the above growth and biomass allocation parameters were calculated according to Hunt (1990) and the units were expressed according to Bugbee (1996).

\section{Experimental design and statistical analysis}

The experiment was arranged in a randomized complete block design with five replications. All pots were rotated within replications (blocks) every day to minimize variation in growth due to possible temperature and light differences within the growth chamber.

Analysis of covariance (ANCOVA), with plant age (days since germination) fitted as covariate, was used to estimate the overall effects of light regime and harvest date and their interaction on biomass allocation parameters. By removing the effect of plant age with the use of ANCOVA, inherent ontogenetic drift effects were avoided Residual plots and normal probability plots were used to check for homoscedastic residuals and normality; when necessary, data were logarithmically transformed. The assumption of homogeneity of slopes (parallelism) was also tested for each ANCOVA. Differences in RGR were tested as a Light regime $\times$ Time interaction in an analysis of variance with logarithmically-transformed dry weight as dependent variable (Poorter \& Lewis, 1986). A trend analysis over time was performed to detect differences in RGR throughout the experiment. Transformed data were back transformed for presentation.

\section{RESULTS AND DISCUSSION}

\section{Biomass allocation}

The ANCOVA showed that, for both species, light regime effects were significant for both leaf area variables, SLA and LAR and for leaf and root mass values (LMR and RMR respectively; $\mathrm{F}_{1.35} \geq 13.38, \mathrm{P} \leq 0.001$ ). Mean values (Table 1 ) for the entire experiment showed that plants grown under low light had greater LAR, LMR and SLA and smaller RMR than plants grown under high light. This tendency in the mean values was maintained throughout the experimental period. The highest SLA and LAR occurred early in plant growth and declined throughout the experimental period. No significant effect $\left(\mathrm{F}_{1.35} \geq 2.15, \mathrm{P} \geq 0.104\right)$ of light regimes on SMR could be detected on either species.

In I. asarifolia, the proportion of biomass allocated to leaf and root tissue, in both high- and low-light treatments, was highest in the beginning of plant development and declined throughout plant growth (Fig. 1). This decline may be in part due to mobilization of resources to the stems. In low-light I. asarifolia, the decline with time in RMR was more pronounced than in the high-light treatment; conversely, high-light plants had a greater decline in LMR (Fig. 1). For S. cayennensis, LMR, under both light regimes, initially increased up to $10 \mathrm{~d}$ and then declined during the experiment (Fig. 2). Root mass ratio changed little with time in low-light S. cayennensis whereas in the high-light treatment RMR had a tendency to increase throughout plant growth (Fig. 2). Allocation to reproductive biomass was observed only in $S$. cayennensis. High-light plants allocated significantly $\left(\mathrm{F}_{1.35}=8.64, \mathrm{P}<0.006\right)$

TABLE 1. Specific leaf area (SLA, $\left.\mathbf{m}^{2} \mathbf{k g}^{-1}\right)$, leaf area ratio (LAR, $\mathbf{m}^{2} \mathrm{~kg}^{-1}$ ), leaf mass ratio (LMR, $\mathrm{kg} \mathrm{kg}^{-1}$ ), stem mass ratio (SMR, $\mathrm{kg} \mathrm{kg}^{-1}$ ) and root mass ratio ( $R M R$, $\mathrm{kg} \mathrm{kg}^{-1}$ ), as means for the entire experiment (40 days), of Stachytarpheta cayennensis and Ipomoea asarifolia under high- and low-light regimes. Values are means ( \pm s.d.), $\mathbf{n = 2 5}$.

\begin{tabular}{lll}
\hline Parameter & \multicolumn{1}{c}{ High-light } & Low-light \\
\hline & \multicolumn{2}{c}{ Stachytarpheta cayennensis } \\
SLA & $30.97(26.8)$ & $48.82(22.7)$ \\
LAR & $18.01(14.62)$ & $30.74(14.12)$ \\
LMR & $0.576(0.112)$ & $0.623(0.093)$ \\
SMR & $0.139(0.061)$ & $0.152(0.065)$ \\
RMR & $0.252(0.053)$ & $0.197(0.038)$ \\
& \multicolumn{2}{c}{ Ipomoea asarifolia } \\
SLA & $22.6(8.1)$ & $32.06(6.6)$ \\
LAR & $89.0(67.2)$ & $136.9(63.2)$ \\
LMR & $0.350(0.141)$ & $0.406(0.129)$ \\
SMR & $0.440(0.169)$ & $0.427(0.177)$ \\
RMR & $0.207(0.052)$ & $0.166(0.063)$ \\
\hline
\end{tabular}


more biomass to reproductive structures (i.e., flower bearing spikes) than low-light plants. This increased allocation to developing flower bearing spikes, together with the larger allocation to roots, apparently contributed to the greater decline with time observed in LMR in high-light $S$. cayennensis relative to low-light plants (Fig. 2).

A common response for low-light plants from both species was a reduced (ca. $20 \%$ ) overall investment into roots relative to high-light plants (Table 1). This is a characteristic feature in many plant species grown under shade, and have been reported in a number of studies (Mahall \& Schlesinger, 1982; Dall'Armellina \& Zimdahl, 1988; Zollinger \& Kells, 1991; Thompson et al., 1992; Walters et al., 1993; Dias-Filho, 1995, 1997). This decreased allocation to roots under low-light conditions has been observed to be maximized mainly in sun-loving plants (Thompson et al., 1992; Walters et al., 1993) and is very likely to be related to traits that
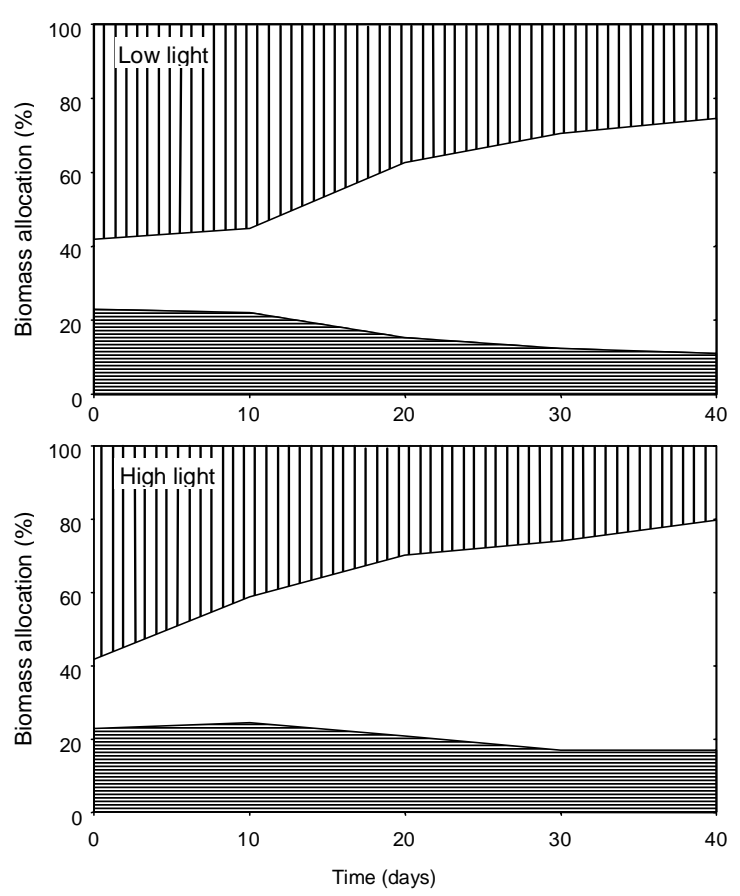

FIG. 1. Mean fraction of biomass allocated to roots (horizontal hatches), stems (blank area) and leaves (vertical hatches) as a function of time and light environment in $I$. asarifolia. improve the rates of carbon gain in low light such as an increased LAR and LMR, or that reflect a light seeking strategy such as vertical growth. In the present study, mean LAR and LMR were, respectively, $71 \%$ and $8 \%$ higher in low-light S. cayennensis and $54 \%$ and $16 \%$ higher in low-light $I$. asarifolia, relative to high-light plants (Table 1). Also, at the last harvest date (40 days), mean plant height (or main stem length in I. asarifolia) was $16 \%$ higher in low-light S. cayennensis $(\mathrm{t}=1.9, \mathrm{P}=0.09)$, but only $7 \%$ longer $(\mathrm{t}=0.68, \mathrm{P}=0.51)$ in low-light $I$. asarifolia. In addition, high-light $I$. asarifolia produced twice as many stems as low-light plants $(\mathrm{t}=3.5, \mathrm{P}=0.002)$.

An important feature observed in S. cayennensis was a significantly higher allocation to developing reproductive structures in high-light plants. Also, low-light grown plants had the onset of flowering delayed in comparison to high-light plants. These
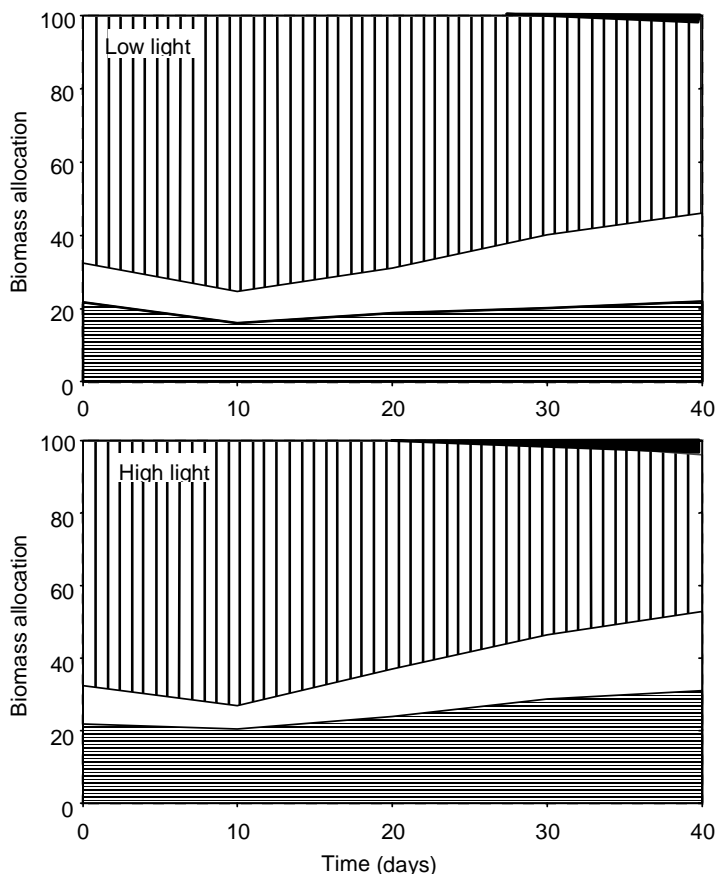

FIG. 2. Mean fraction of biomass allocated to roots (horizontal hatches), stems (blank area), leaves (vertical hatches) and flower bearing spikes (solid area) as a function of time and light environment in $S$. cayennensis. 
results are in accord with the knowledge that in wild plants, reproductive partitioning generally decreases with resource limitation (Chiariello \& Gulmon, 1991), and suggest that in $S$. cayennensis the light environment may provide an important external signal for induction and enhancement of flowering and, as a consequence for the success of this species as a colonizing weed. Similar responses have been described for the perennial weeds Sonchus arvensis (Zollinger \& Kells, 1991), Convolvulus arvensis and Centaurea repens (Dall'Armellina \& Zimdahl, 1988) grown under contrasting light environments.

\section{Growth}

The ANOVA for RGR of I. asarifolia showed a significant Light regime $\mathrm{x}$ Time interaction, indicating that for this species, RGR was influenced by the light regimes experienced by the plants. The trend analysis over time (i.e., orthogonal polynomials) suggested that the differences in RGR between the two light regimes was not maintained throughout the entire experimental period, since the quadratic component accounted for the greatest proportion of the interactive effect (Light regime $x$ Time). An identical response in RGR was also observed for $S$. cayennensis, as the interactive effect of Light regime $\mathrm{x}$ Time was also significant and most of the sum of squares interaction was due to the quadratic component.

For I. asarifolia, high-light grown plants displayed a higher growth rate, relative to low-light plants from the very early stages of seedling development (Fig. 3). This difference in growth between light environments became less pronounced by day 30 , and was not apparent by the last evaluation date. Differences in growth rates between light environments in $S$. cayennensis revealed a similar trend to that observed for I. asarifolia, but, unlike in that species, growth in $S$. cayennensis was exponential for both light regimes (Fig. 3).

Growth in $S$. cayennensis was exponential while in I. asarifolia RGR started to decrease after day 20 or 30, respectively, in high- and low-light plants (Fig. 3). This distinct response between species was probably associated with self-shading and a much larger investment in supporting structures in I. asarifolia which may have inflated the respiration load of this species by decreasing the amount of photosynthetically active area per unit of plant mass. In $S$. cayennensis, due to its growth form, preferential allocation to leaf area (i.e., higher LAR) and leaf arrangement architecture, overall photosynthetic gain was probably unaffected over time relative to I. asarifolia.

Interspecific differences in RGR at the early stages of seedling development (i.e., up to day 20) were well related to initial seedling size and seed weight differences between $I$. asarifolia and S. cayennensis. I. asarifolia has a mean seed mass 44 times greater than that of $S$. cayennensis, and the mean seedling mass at the beginning of the experiment (day 0) was 30 times greater for I. asarifolia. These differences may help maximize the potential of establishment and persistence of I. asarifolia
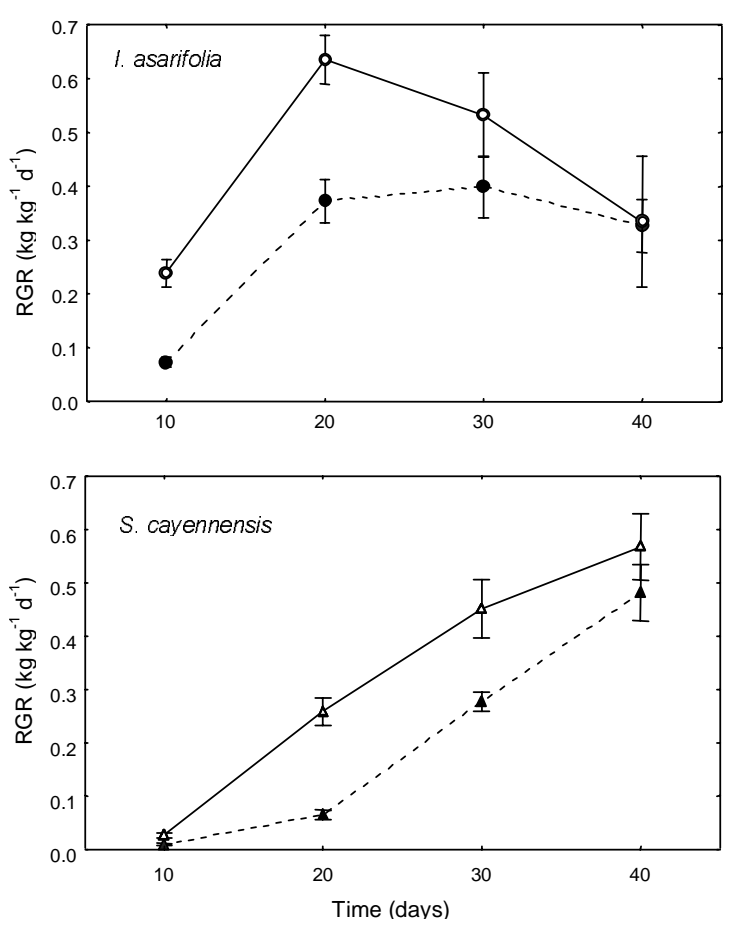

FIG. 3. Change over time in relative growth rates (RGR) (mean $\pm \mathrm{SE}, \mathrm{n}=5$ ) of I. asarifolia and $S$. cayennensis under low- (closed symbols and dashed lines) and high-light (open symbols and solid lines) conditions. 
under conditions of low resource such as in a shaded environment, as observed in the present experiment for low-light plants (Fig. 3).

Light regime during growth had significant effects upon the allocation of carbon and the structure of I. asarifolia and S. cayennensis plants (Table 1). The patterns of biomass allocation reported here for both species are consistent with previous studies which have shown that development under low quantum flux density promotes allocation to leaves and increases SLA (Lambers \& Poorter, 1992). Consistent with their growth form, however, I. asarifolia and $S$. cayennensis differed in the fraction of total plant biomass allocated to leaves, stems and roots. Relative to $S$. cayennensis, I. asarifolia, under both light regimes, partitioned larger portion of biomass into stems and a smaller portion into leaves (Table 1). Being a relatively fast growing vine would require $I$. asarifolia to constantly allocate biomass to stems in order to grow, and as stems are not normally shed during plant growth, their biomass increases steadily over time relative to leaves and roots, which are continually renewed. This characteristic may have contributed to the much higher SMR observed in I. asarifolia relative to $S$. cayennensis on both light regimes (Table 1).

\section{Ecological and weed management implications}

It has been demonstrated that, for tropical tree seedlings, the magnitude of responses in growth and leaf adjustment can vary considerably among species with differential tolerances to shade (Thompson et al., 1992). The present data show that both $S$. cayennensis and I. asarifolia expressed comparable responses in growth and leaf adjustments to low light suggesting a similar ability for dealing with this low resource condition. These characteristics together with the light compensation point derived for each species might be indicative of a similar capacity of $S$. cayennensis and I. asarifolia to tolerate shade quite well.

This study indicates that the light environment has important effects on the structure of I. asarifolia and $S$. cayennensis. These effects may either increase or decrease the competitive ability of these species in an agricultural environment. For example, high-light $I$. asarifolia produced twice as many stems as low-light plants. As, under natural conditions, stem nodes from this species can root when in contact with the soil, and if accidentally separated from the plant, survive as independent plants (Dias-Filho, 1990), high-light I. asarifolia could have a greater competitive advantage over plants grown under low light. Multiple stems in high-light grown I. asarifolia can also be advantageous in competitive situations by inducing the occupation of larger spaces by this species. The present results also show that the light environment may play an important role in determining the competitive ability of $S$. cayennensis, by shortening the time required for the onset of flowering and increasing the relative amount of biomass allocated to reproductive structures in unshaded plants relative to shaded ones (Fig. 2). Because $S$. cayennensis is not capable of vegetative reproduction, the light environment may ultimately affect this weed's infestation potential. Also, as lowlight grown plants from both species allocated a higher proportion of their biomass to leaf area or mass and a smaller proportion to roots than did high-light plants, it could be speculated that plants developed under shade may be relatively more vulnerable to edaphic stress factors, such as drought or low nutrient availability. Conversely, a preferential allocation to roots may further give a competitive advantage to plants developed under full sunlight by enhancing survivorship and promoting resprouting following mowing, fire or herbivory.

If we regard RGR at early stages of seedling development (Fig. 3) as an indication of establishment potential and competitive ability, I. asarifolia seedlings could be considered more competitive than $S$. cayennensis, at least in the short term, under both high and low light environments. Also, the much larger initial seedling size of the large-seeded I. asarifolia may make this species less dependent on high-resource levels and rapid growth rates for early seedling survival, and although both species had their growth potential much reduced in low light (Fig. 3), seedling size in I. asarifolia could also be seen as a potential advantage to deal with low-resources such as reduced light, by enhancing the chances of a successful establishment of this species under such conditions. Furthermore, the growth form of each species: a fast growing herbaceous vine 
(i.e., I. asarifolia) and a relatively slow growing shrub (i.e., S. cayennensis) could also be regarded as an indication of the better adaptation of I. asarifolia to cope with a low-light environment during establishment by facilitating the light seeking capacity of this species. Finally, the above observations could be further corroborated by the fact that germination in I. asarifolia, unlike that in S. cayennensis, which has photoblastic seeds, is not affected by light (Dias-Filho, 1996). Hence, the germination syndrome in I. asarifolia seems to be indicative of a better adaptation of seedlings from this species to start development under low light conditions, while the opposite could be inferred for S. cayennensis.

\section{CONCLUSIONS}

1. Both I. asarifolia and S. cayennensis quickly develop morphological adjustments as buffering mechanisms against light limitation.

2. The biomass allocation response of both species to shade, characterized by a higher carbon investment in above ground tissues relative to roots, might compromise their ability to respond to additional stresses. Due to its growth form, this effect may be more deleterious in $S$. cayennensis.

3 . Because in $S$. cayennensis the onset of flowering and the overall biomass allocation to reproductive structures are negatively affected by shade, development in full light is important for the success of this species as a weed.

\section{ACKNOWLEDGEMENTS}

To Todd Dawson, Sana Gardescu, Peter Marks and one anonymous reviewer that provided valuable suggestions to improve this manuscript.

\section{REFERENCES}

BUGBEE, B.G. Growth analysis and yield components. In: SALISBURY, F.B. (Ed.). Units symbols, and terminology for plant physiology: a reference for presentation of research results in the plant science. New York: Oxford University Press, 1996 p.115-119.
CLOUGH, J.M.; TEERI, J.A.; ALBERTE, R.S. Photosynthetic adaptation of Solanum dulcamara L. to sun and shade environments. Oecologia, v.38, p.13-21, 1979.

CLOUGH, J.M.; TEERI, J.A.; ALBERTE, R.S. Photosynthetic adaptation of Solanum dulcamara L. to sun and shade environments. III. Characterization of genotypes with differing photosynthetic performance. Oecologia, v.44, p.221-225, 1980.

CHIARIELLO, N.R.; GULMON, S.L. Stress effects on plant reproduction. In: MOONEY,H.A.; WINNER, W.E.; PELL, E.J. (Eds.). Response of plants to multiple stresses. San Diego: Academic Press, 1991. p.161-188.

DALL'ARMELLINA, A.A.; ZIMDAHL, R.L. Effect of light on growth and development of field bindweed (Convolvulus arvensis) and Russian knapweed (Centaurea repens). Weed Science, v.36, p.779-783, 1988.

DIAS-FILHO, M.B. Germination and emergence of Stachytarpheta cayennensis and Ipomoea asarifolia. Planta Daninha, v.14, p.118-126, 1996.

DIAS-FILHO, M.B. Physiological response of Solanum crinitum Lam. to contrasting light environments. Pesquisa Agropecuária Brasileira, Brasília, v.32, n.8, p.789-796, 1997.

DIAS-FILHO, M.B. Physiological responses of Vismia guianensis to contrasting light environments. Revista Brasileira de Fisiologia Vegetal, v.7, p.35-40, 1995

DIAS-FILHO, M.B. Plantas invasoras em pastagens cultivadas da Amazônia: estratégias de manejo e controle. Belém: Embrapa-CPATU, 1990. 103p. (Embrapa-CPATU. Documentos, 52).

ELMORE, C.D.; HURST, H.R.; AUSTIN, D.F. Biology and control of morningglories (Ipomoea spp.). Reviews in Weed Science, v.5, p.83-144, 1990.

GIVNISH, T.J. Adaptation to sun and shade: a wholeplant perspective. Australian Journal of Plant Physiology, v.15, p.63-92, 1988

GRONINGER, J.W.; SEILER, J.R.; PETERSON, J.A.; KREH, R.E. Growth and photosynthesis responses of four Virginia Piedmont tree species to shade. Tree Physiology, v.16, p.773-778, 1996.

HASELWOOD, E.L.; MOTTER, G.G. Handbook of Hawaiian weeds. 2.ed. Honolulu: Univ. of Hawaii Press, 1983. 491p

Pesq. agropec. bras., Brasília, v.34, n.6, p.945-952, jun. 1999 
HOLT, J.S. Plant response to light: a potential tool for weed management. Weed Science, v.43, p.474-482, 1995.

HUNT, R. Basic growth analysis: plant growth analysis for beginners. London: Unwin Hyman, 1990. 112p.

KLEINSCHMIDT, H.E.; JOHNSON, R.W. Weeds of Queensland. Brisbane: Queensland Department of Primary Industries, 1987. 469p.

LAMBERS, H.; POORTER, H. Inherent variation in growth rate between higher plants: a search for physiological causes and ecological consequences. Advances in Ecological Research, v.23, p.187-261, 1992

MAHALL, B.E.; SCHLESINGER, W.H. Effects of irradiance on growth, photosynthesis, and water use efficiency of seedlings of the Chaparral shrub, Ceanothus megacarpus. Oecologia, v.54, p.291299, 1982

NAIR, N.C.; MOHANAN, C.N.; SREEKUMAR, P.V Stachytarpheta cayennensis (L.C. Rich) Schan. A new record for India with a key to Indian species. Journal of Bombay Natural History Society, v.79, p.230-232, 1982.

POORTER, H.; LEWIS, C. Testing the differences in relative growth rate: A method avoiding curve fitting and pairing. Physiological Plantarum, v.67, p.223226, 1986

SEEMANN, J.R. Light adaptation/acclimation of photosynthesis and the regulation of ribulose-1, 5-bisphosphate carboxylase activity in sun and shade plants. Plant Physiology, v.91, p.379- 386, 1989.

THOMPSON, W.A.; KRIEDEMANN, P.E.; CRAIG, I.E Photosynthetic response to light and nutrients in suntolerant and shade-tolerant rainforest trees. I. Growth, leaf anatomy and nutrient content. Australian Journal of Plant Physiology, v.19, p.1-18, 1992

WALTERS, M.B.; FIELD, C.B. Photosynthetic light acclimation in two rainforest Piper species with different ecological amplitudes. Oecologia, v.72, p.449-456, 1987.

WALTERS, M.B.; KRUGER, E.L.; REICH, P.B. Growth, biomass distribution and $\mathrm{CO}_{2}$ exchange of northern hardwood seedlings in high and low light: relationships with successional status and shade tolerance. Oecologia, v.94, p.7-16, 1993.

ZOLLINGER, R.K.; KELLS, J.J. Effect of soil pH, soil water, light intensity, and temperature on perennial sowthistle (Sonchus arvensis L.). Weed Science, v.39, p.376-384, 1991 